\title{
Influence of Organizational Structure on the Quality of Computerized Accounting Systems among Small and Medium Enterprises in Nigeria
}

\author{
Akamanwam Effiong Itang \\ Doctoral Candidate of Finance and Accounting, LIGS University, Honolulu, Hawaii, USA
}

\begin{abstract}
This study examined the influence of organizational structure on the quality of computerized accounting systems among small and medium enterprises in Nigeria. The method employed in the research was the survey methodology with the use of self-completed questionnaires administered to accounting/finance personnel, each from the sample of 370 firms selected from the population of 9,276 SMEs within the south-south region of Nigeria. The research data was analyzed using frequencies and the Pearson Product-Moment Correlation that was subjected to a t-transformation test. The results of the study indicate that there is a positive relationship between organizational structure and the quality of computerized accounting systems among SMEs, and that, overall, organizational structure has a positive influence on the quality of computerized accounting systems. This result implies that the form of organizational structure practiced by firms play significant role in determining the quality of their computerized accounting systems. Those managing SMEs as well as other practitioners and scholars would find the results of this study useful. The researcher has also suggested areas for further research that would help revalidate or extend the outcome of this study.

Keywords: Accounting information systems, Accounting information systems quality, Accounting software quality, Centralization, Computerized accounting systems, Formalization, Organizational structure, Small and medium enterprises, Quality of computerized accounting systems
\end{abstract}

DOI: $10.7176 / \mathrm{RJFA} / 11-22-08$

Publication date: November $30^{\text {th }} 2020$

\section{Introduction}

Decision-making is a crucial aspect of the management process in every organization and depends largely on the quality of available information, which in turn depends on the quality of the system from which the information is derived. Accounting is the information system that provides information on the economic activities of an organization for effective decision making (AICPA, 1966; Kimmel et al., 2011). In today's technology-driven environment, the accounting function in most organizations has migrated from manual to computerized systems. Computerized accounting systems (accounting information systems) are, therefore, technology-based systems that involve "the application of computers and related technologies in the collection, recording, storing, and processing of financial data, and interpreting and reporting financial information to stakeholders" for decision making purposes (Itang, 2020a, p.39). However, the nature and quality of financial information generated from the accounting information system would certainly depend on the quality of the system itself. The basic qualities of accounting information systems have been indicated to include integration, flexibility, efficiency, accessibility, reliability, and timeliness (Meiryani, Susanto, \& Sudrajat, 2019; Nicolaou, 2011; Stair \& Reynolds, 2010). Based on systems theory, the integration quality has been decoupled by Itang (2020a) into what is termed structural characteristics of the computerized accounting systems (accounting information systems), namely, internal controls, automated data-processing, relational database, automated reporting, and enhancing technologies components. Therefore, organizations have in recent times made efforts to adopt computerized accounting systems that poses optimal qualities. Despite these efforts, it has been indicated that, in practice, certain factors such as organizational structure, culture, size, management style and support, and user ability, exert some level of influence over the quality, effectiveness and efficiency of such systems (see Haleem, 2006; Kuraesin et al., 2019; Meiryani, 2014; Napitulupu, 2015; Nguyen \& Nguyen, 2020; Omar et al., 2016; Thuan \& Huong, 2019; Wisna, 2015). Considering organizational structure in particular, a few studies have been carried out on its influence on, or relationship with, quality of accounting information systems (see for example, Omar et al., 2016). However, there is no studies that focuses on the Nigerian environment in that regard. This study, therefore, aims to extend previous studies by examining the influence of organizational structure on the quality of computerized accounting systems among Nigerian firms with emphasis on small and medium enterprises (SMEs).

To achieve the above indicated aim and objective, the following research question was asked: What is the relationship between organizational structure and quality of computerized accounting systems among small and medium enterprises in Nigeria?

In line with the above research question, the following hypothesis was tested:

$\mathrm{H}_{\mathrm{O}}$ : Organizational structure does not influence the quality of computerized accounting systems among 
SMEs in Nigeria.

This study is significant as it would extend the body of knowledge as well as bridge the gap in existing literature in accounting, and particularly, accounting information systems. The study's result would be useful to those in the academia as well as decision-makers, managers, and accounting personnel in SMEs. The remaining sections of the paper presents the literature review, methods, study results, discussions, conclusions, and recommendations, respectively.

\section{Literature Review}

\subsection{Organizational Structure}

Organizational structure has been defined in diverse ways by different scholars. However, the diversity in definitions notwithstanding, the basic elements underlying organizational structure remains the same in all the definitions. According to Agbim (2013, p. 57), organizational structure is "a framework of roles, responsibilities, authority and communication relationships that are deliberately designed to accomplish an organization's tasks and achieve its objectives". Shabbir (2017, p. 1) sees organizational structure as "the placement of organizational members into strategic positions of responsibility with authority, with a view to achieving organizational objectives". Also put differently by Ogbo, et al. (2015, p. 1280), organizational structure is "the way in which functions or tasks are grouped and assigned, and the manner in which relationships are coordinated between superiors and subordinates within any organization". From the foregoing definitions, the underlying elements in organizational structure include deliberate design, authority and control, tasks and responsibilities, processes and communication, coordination, and purpose. By deliberate design it means that the structure of an organization is cannot be accidental but deliberately established; authority and control implies that an organizational structure is characterized by clearly defined lines of authority and spans of control; tasks and responsibilities indicates roles and job functions that members are expected to fulfil; processes and communication flows establishes the work processes and directions of communication; coordination helps to maintain a balance and harmony amongst the various elements within the structure; while purpose represents the reason for establishing the structure, which is to enable the organization achieve its objectives. As a working definition, therefore, organizational structure is a framework consciously established within an organization that defines lines of authority, responsibilities, job functions, and communication channels, and how these are coordinated and harmonized to enable the organization to achieve its set goals and objectives.

Burns and Stalker (1961) as cited in Agbim (2013, p. 57), identified two major types of organizational structure, namely:

i) Mechanistic structure, which is most suitable for organizations operating within environments that are stable; and

ii) Organic structures, which is most suitable for organizations operating within unstable environments.

Generally, organizational structure, whether mechanistic or organic, have been further decomposed into several dimensions such as centralization, formalization, integration, differentiation, specialization, departmentalization, and complexity (see Cosh, Fu, \& Hughes, 2012; Daft, 2010; Damanpour, 1991; Janicijevic, 2013; Shabbir, 2017). However, it has been argued that specialization is the result of differentiation, and departmentalization the product of integration, and not direct dimensions of organizational structure; while complexity represents the extent of sophistication resulting from degrees of concentration, formalization, integration, and differentiation in organizational structure (Janicijevic, 2013). Therefore, for the purpose of this study, emphasis would be placed on centralization, formalization, integration, and differentiation, as the major dimensions of organizational structure, each of which is conceptualized below.

- Centralization: This entails the number of hierarchical levels established in an organization for the exercise of authority and decision-making. Organizations could be centralized in structure, with authority and decision-making vested in top levels, or decentralized, with authority and decisionmaking dispersed at the lower levels of the organization (Vazifedoust, Nasiri, \& Norouzi, 2012).

- Formalization: This dimension of organizational structure entails the establishment of rights, roles and duties for individual members and the documentation of rules and procedures within the organization (Willem, Buelens, \& De Jonghe, 2007).

- Integration: This involves grouping members of the organization into various units or departments based on their roles and functions and ensuring that these units are properly coordinated and harmonized towards achieving the overall goals of the organization (Janicijevic, 2013).

- Differentiation: This dimension of organizational structure involves the compartmentation of operational and managerial activities within the organization. Operational activities are usually differentiated through division of labor and job design, while managerial activities are differentiated by defining decision-making roles and positions (Janicijevic, 2013). Operational and managerial differentiation, therefore, determines the degrees of centralization (or decentralization) 
and integration dimensions of an organization's structure.

\subsection{Computerized Accounting Systems and their Quality Measures}

The accounting system is an aspect of an organization's framework that is designed to collect and process financial data as well as report information on the economic activities of the organization. (Hurt, 2013), and it has gradually migrated from the originally manual processes to computerized ones (Itang 2017). Computerized accounting systems (CAS), therefore, "involves the application of computers and related technologies in the collection, recording, storing, and processing of financial data, and interpreting and reporting financial information to stakeholders" (Itang, 2020a, p.39). The emergence of computerized accounting systems has led to the development of several accounting software by various software vendors to meet the needs both small and large organizations (Ismail \& King, 2006), some of which are distributed commercially while others are available as open source applications (Mujat et al., 2013). The major advantages of accounting software include the fact that they enable the performance of the various stages in the accounting cycle with less human efforts, increased processing speed, accuracy, ease of retrieval of information, and employees motivation (Itang, 2017; Mujat et al., 2013). The emergence of cloud computing has also availed organizations with the benefit of using accounting applications on the web (cloud) without having to maintain any software or storage facilities in their offices (Wyslocka \& Jelonek, 2015). Small and medium enterprises have been indicated to embrace the use of these computerized accounting systems in recent times, and the most adopted of such systems include QuickBooks, Peachtree (Sage 50), MSNavision, Sage Pastel (Evolution), Tally ERP (Amidu, Effah \& Abor, 2011; Itang, 2017, 2018, 2020 b).

The available accounting software are indicated to possess some characteristics, which typically defines the qualities and performance measures of the systems (Meiryani, 2014; Wisna, 2015). These performance measures could be expressed in terms of qualitative characteristics such as ease-of-use, flexibility, reliability, accessibility, speed, and accuracy (Meiryani et al., 2019; Thuan \& Huong, 2019; Stair \& Reynolds, 2010), as well as structural characteristics, namely, internal controls, automated data-processing, relational database, automated reporting, and enhancing technologies (Itang, 2020a). For the computerized accounting system to be reliable, it should be able to generate quality information (Stair \& Reynolds, 2010), while integration ensures that the various components of the system such as hardware, data, people, procedures, and network devices are properly interrelated and coordinated for the successful functioning of the entire system (Susanto, 2013). As indicated by Itang (2020a), internal controls are essential to ensure authorization and authentication of users' access, accuracy of data, segregation of duties, data security and integrity, and maintenance of audit trail; automated data processing ensures that the accounting process is performed within the system without human intervention; relational database component ensures that the system has the capacity to store and retrieve large amount of data and information; automated reporting is the ability of the system to automatically generate reports based on predefined parameters; while the enhancing technologies refer to the various technological tools and devices adaptable to the system to enhance its efficiency, such as network devices, point-of-sale equipment, messaging and mailing applications, etc.

\subsection{Organizational Structure and Quality of Computerized Accounting Systems}

Like it is with every other computerized organizational function, the quality of computerized accounting systems employed by organizations is indicated to be influenced by certain factors including firm characteristics such as the structure, culture, and size of the organization. As noted by Kieso, Weygandt, and Warfield (2016), organizational structure plays a significant role in the successful implementation of accounting information systems among firms. Mukherji (2002), while studying the impact of information systems on organizations and structures, found that organizational structures and accounting information systems are interrelated and that both depend on each other for the holistic success of the organization.

Previous studies have indicated that organizational structure influences the quality of accounting information systems employed by firms. In a study on factors that influence the quality of accounting information systems among Malaysian private firms, Omar et al. (2016), using a quantitative cross-sectional method, administered standardized questionnaire to a convenient sample of 100 management and operational personnel with knowledge of accounting information systems selected from firm in various locations in Kuala Lumpur, Malaysia, found that that there is a significant relationship between organizational structure and quality of accounting information systems employed by firms. Salehi and Abdipour (2011), in their study of the barriers of accounting information systems implementation among listed firms in Tehran stock exchange, Turkey also indicated that organizational structure could impede the application of accounting information systems by firms. Nagappan, Murphy, and Basili (2009), in their study titled "The Influence of Organizational Structure on Software Quality: An Empirical Case Study", indicated that organizational structure has influence on the quality and effectiveness of accounting software implemented by organizations.

The results of the above reviewed studies support the position of Bouwens and Abernethy (2000) that the development and implementation of accounting information systems would not be successful without the consideration of the firm's organizational structure. However, none of the above indicated studies was conducted 
in the West African sub-region or Nigeria and hence, their results may not be conveniently generalized to firm in the country. The present study, therefore, sought to examine the influence of organizational structure on quality of computerized accounting systems among firms in Nigeria, with a focus on SMEs. Hence, the study hypothesis was postulated thus:

$\mathrm{H}_{\mathrm{O}}$ : Organizational structure does not influence the quality of computerized accounting systems among SMEs in Nigeria

\section{Methods}

\subsection{Study Design}

The survey methodology was employed in this study, basically due to its advantages of inexpensiveness, quick data gathering, and allowance for empirical inferences (Kpolovie, 2016; Salhin et al., 2016; Totten, Panacek \& Price, 1999). The 25-item CAS measurement tool developed by Itang (2020a) was adopted for assessing the quality of computerized accounting systems, while the scale employed by Kalay and Lynn (2016, p. 137) was adopted for assessing organizational structure in terms of centralization (6 items) and formalization (4 items). The above adopted scales were incorporated into the three-part questionnaire (see sample copy in Appendix) that was administered for the study.

\subsection{Operationalization of the Study Variables}

In this study, the independent variable, organizational structure, was operationalized based on two dimensions, namely centralization and formalization, with six measurement indicators for centralization and four for formalization. The dependent variable, quality of computerized accounting systems (CAS), on the other hand, was operationalized using the five structural characteristics posited by Itang (2020a), namely, internal controls, automated data-processing, relational database, automated reporting, and enhancing technologies. The details of the measures and indicators employed for each of the dimensions of organizational structure and quality of CAS are presented in Table 1.

Table 1. Operationalization of Study Variables

\begin{tabular}{|c|c|c|}
\hline Variable & Dimension & Measure/Indicator \\
\hline \multirow[t]{10}{*}{ Organizational structure } & Centralization (SC) & Decision-making (SC1) \\
\hline & & Reporting (SC2) \\
\hline & & Superior's influence (SC3) \\
\hline & & Approvals (SC4) \\
\hline & & Consultation (SC5) \\
\hline & & Personal initiative (SC6) \\
\hline & Formalization (SF) & Standards/procedures (SF1) \\
\hline & & Rules/regulations (SF2) \\
\hline & & Required compliance (SF3) \\
\hline & & Communication (SF4) \\
\hline \multirow[t]{22}{*}{ CAS quality } & Internal controls (IC) & Access controls (IC1) \\
\hline & & Segregation of duties (IC2) \\
\hline & & Accuracy checks (IC3) \\
\hline & & Security controls (IC4) \\
\hline & & Audit trail (IC5) \\
\hline & Automated data-processing (AP) & Seamless processing (AP1) \\
\hline & & Data validation (AP2) \\
\hline & & Transaction posting (AP3) \\
\hline & & Accounts balancing (AP4) \\
\hline & & Accounts reconciliation (AP5) \\
\hline & Relational database (RD) & Large storage (RD1) \\
\hline & & Data maintenance (RD2) \\
\hline & & Data independence (SRD3) \\
\hline & & Backup/recovery (SRD4) \\
\hline & & Concurrent access (SRD5) \\
\hline & Automated reporting (AR) & Seamless reporting (SAR1) \\
\hline & & Trial balance (SAR2) \\
\hline & & Financial statements (SAR3) \\
\hline & & Multiple formats (SAR4) \\
\hline & & Comparative reports (SAR5) \\
\hline & Enhancing technologies (ET) & Networking (SET1) \\
\hline & & Cloud computing (SET2) \\
\hline
\end{tabular}


Source: Adapted from Kalay and Lynn (2016) and Itang (2020a)

\subsection{Study Population and Sample}

SMEs operating within the south-south region of Nigeria formed the population of the study. As indicated by SMEDAN (2013), there are 9,276 SMEs in the south-south region of Nigeria and a random sample of 370 firms was drawn using the Krejcie and Morgan (1970) sample size determination table.

\subsection{Data Collection and Analysis}

A self-completed questionnaire was used to collect data for the study. The questionnaire was distributed to one finance and accounting officer in each of the 370 sampled firms., and 220 useful responses were received, giving an acceptable response rate of $60 \%$. The research data were analyzed using frequencies and the Pearson ProductMoment Correlation with the help of the SPSS-Statistics software. As indicated by Laerd Statistics (n.d.), the Pearson correlation coefficient ( $\mathrm{r}$ ) ranges from -1 to +1 , with a value less than 0 indicating a negative association, zero (0) indicating no association, and a value greater than 0 indicating a positive association. In testing the hypothesis, the significance of the correlation coefficients (r) was determined using the t-test transformation test, based on which the study hypotheses were rejected or accepted.

\subsection{Reliability Tests}

Though the measurement scales for the study was adopted from previously tested instruments, the researcher found it necessary to check the reliability of the scales considering the difference in the present study's context and scope. The Cronbach Alpha test of internal reliability (consistency) was used to test the reliability of the research instrument , and as shown in Table 2, the result indicated that individual items on each of the rating scales have Cronbach's alpha coefficient $(\alpha)$ greater than 0.8 and satisfactory and acceptable total item Cronbach's alpha coefficient $(\alpha)$ of 0.946 and 0.928 for CAS and organizational structure measurement scales, respectively, which indicated that the research instrument was reliable and the results, therefore, generalizable.

Table 2. Cronbach Alpha Test of Reliability

\begin{tabular}{|c|c|c|c|c|}
\hline Construct & Item & $\begin{array}{l}\text { Item Cronbach's } \\
\text { alpha }(\alpha)\end{array}$ & $\begin{array}{l}\text { Total } \\
\text { Cronbach's } \\
(\alpha)\end{array}$ & Reliability \\
\hline \multirow[t]{5}{*}{ CAS scale } & Internal controls & 0.830 & 0.946 & High \\
\hline & Automated data-processing & 0.877 & & \\
\hline & Relational database & 0.819 & & \\
\hline & Automated reporting & 0.816 & & \\
\hline & Enhancing technologies & 0.898 & & \\
\hline \multirow{2}{*}{$\begin{array}{l}\text { Organizational } \\
\text { structure scale }\end{array}$} & Centralization & 0.891 & 0.928 & High \\
\hline & Formalization & 0.926 & & \\
\hline
\end{tabular}

Source: Research data analysis output from SPSS-Statistics

\section{Study Results}

4.1 Descriptive Analysis of Respondents

The respondents to the survey were finance and accounting officers, one from each of the sampled firms. As shown in Table 3, most of the respondents (40\%) were Accountants or Account Officers, while 23.2\% were Chief Accountants. Respondents with the job title of Finance or Accounts Manager were $21.8 \%$ and Chief Finance Officers of Financial Controllers were 10.9\%, while 41\% were Auditors.

Table 3. Distribution of Respondents by Job Title

\begin{tabular}{lrrr}
\hline \multicolumn{1}{c}{ Job title } & Frequency & Percentage (\%) & Cumulative \% \\
\hline Accountant/Account Officer & 88 & 40.0 & 40.0 \\
Chief Accountant & 51 & 23.2 & 63.2 \\
Finance/Accounts Manager & 48 & 21.8 & 85.0 \\
CFO/Financial Controller & 24 & 10.9 & 95.9 \\
Auditor & 9 & 4.1 & 100.0 \\
Total & $\mathbf{2 2 0}$ & $\mathbf{1 0 0}$ & \\
\hline
\end{tabular}

Source: Research data analysis output from SPSS-Statistics 


\subsection{Relationship between Organizational Structure and Quality of CAS}

The objective of the study was to examine the relationship between organizational structure and quality of computerized accounting systems (CAS) among Nigerian SMEs. The Pearson Product Moment Correlation (PPMC) statistics was used in determining whether any relationship exists between the two variables. The result of the PPMC analysis, which is presented in Table 4, indicates that the correlation coefficients for all the measures and indicators of organizational structure and CAS are positive, with values ranging between 0.053 and 0.683. These results indicate that positive relationship exists between each measures of organizational structure and the indicators of computerized accounting systems quality. Therefore, in answer to the research question, it could be maintained that there is a positive relationship between organizational structure and quality of computerized accounting systems among SMEs in Nigeria.

Table 4. Correlation coefficients for Organizational Structure and CAS Quality Indicators *

\begin{tabular}{|l|l|l|l|l|l|l|l|l|l|l|}
\hline & OSC1 & OSC2 & OSC3 & OSC4 & OSC5 & OSC6 & OSF1 & OSF2 & OSF3 & OSF4 \\
\hline SIC1 & 0.497 & 0.344 & 0.404 & 0.276 & 0.331 & 0.347 & 0.396 & 0.411 & 0.430 & 0.380 \\
\hline SIC2 & 0.648 & 0.392 & 0.517 & 0.353 & 0.375 & 0.446 & 0.484 & 0.533 & 0.494 & 0.422 \\
\hline SIC3 & 0.285 & 0.348 & 0.397 & 0.506 & 0.494 & 0.401 & 0.459 & 0.374 & 0.505 & 0.554 \\
\hline SIC4 & 0.515 & 0.495 & 0.477 & 0.390 & 0.327 & 0.385 & 0.652 & 0.683 & 0.612 & 0.600 \\
\hline SIC5 & 0.302 & 0.396 & 0.277 & 0.478 & 0.392 & 0.238 & 0.377 & 0.379 & 0.325 & 0.455 \\
\hline SAP1 & 0.053 & 0.358 & 0.318 & 0.466 & 0.528 & 0.283 & 0.091 & 0.120 & 0.077 & 0.206 \\
\hline SAP2 & 0.303 & 0.532 & 0.497 & 0.674 & 0.615 & 0.376 & 0.410 & 0.413 & 0.403 & 0.579 \\
\hline SAP3 & 0.193 & 0.390 & 0.372 & 0.512 & 0.568 & 0.330 & 0.297 & 0.184 & 0.310 & 0.438 \\
\hline SAP4 & 0.277 & 0.457 & 0.446 & 0.578 & 0.512 & 0.293 & 0.106 & 0.160 & 0.113 & 0.260 \\
\hline SAP5 & 0.275 & 0.345 & 0.377 & 0.555 & 0.531 & 0.394 & 0.387 & 0.296 & 0.370 & 0.499 \\
\hline SRD1 & 0.318 & 0.371 & 0.382 & 0.453 & 0.314 & 0.312 & 0.291 & 0.333 & 0.217 & 0.369 \\
\hline SRD2 & 0.325 & 0.477 & 0.329 & 0.412 & 0.338 & 0.376 & 0.561 & 0.465 & 0.534 & 0.544 \\
\hline SRD3 & 0.225 & 0.437 & 0.427 & 0.499 & 0.480 & 0.244 & 0.442 & 0.459 & 0.294 & 0.476 \\
\hline SRD4 & 0.236 & 0.411 & 0.411 & 0.510 & 0.483 & 0.255 & 0.454 & 0.473 & 0.299 & 0.495 \\
\hline SRD5 & 0.159 & 0.266 & 0.351 & 0.494 & 0.533 & 0.173 & 0.218 & 0.284 & 0.152 & 0.389 \\
\hline SAR1 & 0.363 & 0.446 & 0.306 & 0.426 & 0.392 & 0.307 & 0.188 & 0.263 & 0.225 & 0.261 \\
\hline SAR2 & 0.501 & 0.411 & 0.425 & 0.526 & 0.425 & 0.434 & 0.223 & 0.262 & 0.217 & 0.222 \\
\hline SAR3 & 0.280 & 0.481 & 0.415 & 0.475 & 0.517 & 0.615 & 0.497 & 0.526 & 0.372 & 0.541 \\
\hline SAR4 & 0.522 & 0.320 & 0.523 & 0.518 & 0.520 & 0.520 & 0.445 & 0.544 & 0.364 & 0.460 \\
\hline SAR5 & 0.215 & 0.455 & 0.330 & 0.513 & 0.522 & 0.388 & 0.519 & 0.494 & 0.450 & 0.568 \\
\hline SET1 & 0.399 & 0.387 & 0.459 & 0.455 & 0.524 & 0.480 & .536 & 0.607 & 0.438 & 0.526 \\
\hline SET2 & 0.452 & 0.440 & 0.503 & 0.575 & 0.554 & 0.465 & .472 & 0.596 & 0.265 & 0.485 \\
\hline SET3 & 0.233 & 0.528 & 0.525 & 0.579 & 0.701 & 0.374 & .442 & 0.516 & 0.256 & 0.543 \\
\hline SET4 & 0.340 & 0.397 & 0.438 & 0.615 & 0.650 & 0.387 & .437 & 0.488 & 0.214 & 0.458 \\
\hline SET5 & 0.222 & 0.466 & 0.407 & 0.565 & 0.614 & 0.394 & .398 & 0.480 & 0.220 & 0.427 \\
\hline
\end{tabular}

$* \mathrm{~N}=220$; Significant at $\mathrm{p}<0.05$ (2-tailed).

Source: Research Data Analysis Output Extract from SPSS-Statistics

\subsection{Test of Hypothesis}

The hypothesis of the study, stated in its null form, was that organizational structure does not influence the quality of computerized accounting systems among SMEs in Nigeria. For a more reliable result, the derived correlation coefficients shown in Table 3 were subjected to the t-transformation test using the following formula:

$\mathrm{t}=[\mathrm{r} \sqrt{ }(\mathrm{N}-2)] \div[\sqrt{ }(\mathrm{r}-\mathrm{r} 2)]$

where: $\mathrm{r}=$ Correlation coefficient; $\mathrm{N}=$ Number of paired scores.

The calculated t-values (see Table 5) were compared with the critical t-values at 0.05 level of confidence, with 218 degrees of freedom. The null hypothesis was rejected where the calculated t-value is greater than the critical t-value of 1.962 , else it was accepted. 
Table 5. Calculated t-Values Using t-Transformation Formula

\begin{tabular}{|c|c|c|c|c|c|c|c|c|c|c|}
\hline & OSC1 & OSC2 & OSC3 & OSC4 & OSC5 & OSC6 & OSF1 & ODF2 & OSF3 & OSF4 \\
\hline SIC1 & 7.838 & 5.554 & 6.456 & 4.522 & 5.358 & 5.599 & 6.336 & 6.560 & 6.844 & 6.096 \\
\hline SIC2 & 10.045 & 6.276 & 8.133 & 5.690 & 6.021 & 7.082 & 7.646 & 8.369 & 7.794 & 6.725 \\
\hline SIC3 & 4.659 & 5.614 & 6.351 & 7.971 & 7.794 & 6.411 & 7.275 & 6.006 & 7.956 & 8.677 \\
\hline SIC4 & 8.104 & 7.809 & 7.542 & 6.246 & 5.297 & 6.171 & 10.103 & 10.550 & 9.523 & 9.349 \\
\hline SIC5 & 4.918 & 6.336 & 4.537 & 7.557 & 6.276 & 3.940 & 6.051 & 6.081 & 5.267 & 7.216 \\
\hline SAP1 & 1.007 & 5.765 & 5.161 & 7.379 & 8.295 & 4.629 & 1.631 & 2.097 & 1.403 & 3.446 \\
\hline SAP2 & 4.933 & 8.354 & 7.838 & 10.420 & 9.567 & 6.036 & 6.545 & 6.590 & 6.441 & 9.043 \\
\hline SAP3 & 3.244 & 6.246 & 5.976 & 8.059 & 8.882 & 5.343 & 4.842 & 3.104 & 5.040 & 6.963 \\
\hline SAP4 & 4.537 & 7.246 & 7.082 & 9.028 & 8.059 & 4.781 & 1.873 & 2.729 & 1.985 & 4.277 \\
\hline SAP5 & 4.507 & 5.569 & 6.051 & 8.691 & 8.339 & 6.306 & 6.201 & 4.827 & 5.946 & 7.868 \\
\hline SRD1 & 5.161 & 5.961 & 6.126 & 7.186 & 5.100 & 5.070 & 4.751 & 5.388 & 3.616 & 5.931 \\
\hline SRD2 & 5.267 & 7.542 & 5.327 & 6.575 & 5.464 & 6.036 & 8.779 & 7.364 & 8.383 & 8.530 \\
\hline SRD3 & 3.740 & 6.948 & 6.799 & 7.868 & 7.587 & 4.032 & 7.023 & 7.275 & 4.796 & 7.527 \\
\hline SRD4 & 3.909 & 6.560 & 6.560 & 8.030 & 7.631 & 4.201 & 7.201 & 7.483 & 4.872 & 7.809 \\
\hline SRD5 & 2.713 & 4.369 & 5.660 & 7.794 & 8.369 & 2.933 & 3.632 & 4.644 & 2.603 & 6.231 \\
\hline SAR1 & 5.840 & 7.082 & 4.979 & 6.784 & 6.276 & 4.994 & 3.166 & 4.323 & 3.740 & 4.293 \\
\hline SAR2 & 7.897 & 6.560 & 6.769 & 8.266 & 6.769 & 6.904 & 3.709 & 4.308 & 3.616 & 3.693 \\
\hline SAR3 & 4.583 & 7.602 & 6.620 & 7.513 & 8.133 & 9.567 & 7.838 & 8.266 & 5.976 & 8.486 \\
\hline SAR4 & 8.207 & 5.191 & 8.221 & 8.148 & 8.177 & 8.177 & 7.067 & 8.530 & 5.856 & 7.290 \\
\hline SAR5 & 3.585 & 7.216 & 5.343 & 8.074 & 8.207 & 6.216 & 8.163 & 7.794 & 7.142 & 8.882 \\
\hline SET1 & 6.381 & 6.201 & 7.275 & 7.216 & 8.236 & 7.587 & 8.413 & 9.451 & 6.963 & 8.266 \\
\hline SET2 & 7.171 & 6.993 & 7.927 & 8.984 & 8.677 & 7.364 & 7.468 & 9.291 & 4.354 & 7.661 \\
\hline SET3 & 3.863 & 8.295 & 8.251 & 9.043 & 10.808 & 6.006 & 7.023 & 8.118 & 4.216 & 8.515 \\
\hline SET4 & 5.494 & 6.351 & 6.963 & 9.567 & 10.074 & 6.201 & 6.948 & 7.705 & 3.570 & 7.261 \\
\hline SET5 & 3.693 & 7.379 & 6.501 & 8.838 & 9.552 & 6.306 & 6.366 & 7.587 & 3.663 & 6.799 \\
\hline
\end{tabular}

Source: Researcher's Computation Based on t-Transformation Formula

Table 5 shows that the calculated t-value for each of the correlation coefficients (ranging between 1.985 and $10.808)$ is greater than the critical t-value (1.962) at 0.05 level of significance and degrees of freedom of 218 ; except for four pairs, namely, OSC1 - Decision-making/SAP1 - Seamless processing (t-value = 1.007), OSF1 Standards-procedures/SAP1 - Seamless processing $(\mathrm{t}$-value $=1.631)$, OSF3 - Required compliance/SAP1 Seamless processing $(\mathrm{t}$-value $=1.403)$, and OSF $1-$ Standards-procedures $/ \mathrm{SAP} 4-$ Accounts balancing $(\mathrm{t}$-value $=$ 1.873), representing an insignificant $1.6 \%$ of the pairs of relationships. Hence, the null hypothesis that organizational structure does not influence the quality of computerized accounting systems among SMEs in Nigeria is rejected. The study, therefore, indicates that that organizational structure has positive influence on the quality of computerized accounting systems among small and medium enterprises.

\section{Discussion and Conclusion}

\subsection{Discussion of the Results}

The objective of the study was to examine the relationship between organizational structure and the quality of computerized accounting systems and to ascertain the influence of organization structure on the quality of computerized accounting systems among small and medium enterprises (SMEs) in Nigeria. Two dimensions of organizational structure (centralization and formalization) and five dimensions of computerized accounting systems (CAS) quality measures (internal controls, automated data-processing, relational database, automated reporting, and enhancing technologies) were considered in the study. A total of ten indicators were used to measure organizational structure, while CAS quality was assessed using a total of 25 indicators (see Table 1). The results of the study show that there is a positive relationship between organizational structure and quality of computerized accounting systems among SMEs in Nigeria.

However, the study shows that out of the 250 pairs of variables indicators, no relationship exists between four pairs, namely, centralized decision-making/system seamless processing, formal compliance requirement/system seamless processing, formal standards and procedures/system seamless processing, and formal standards and procedures/system accounts-balancing. This implies that seamless processing and accounts balancing characteristics of computerized accounting systems, being two of the fundamental features of the systems, are not influenced by organizational structure in terms of decision-making process, standards, procedures, rules , regulations, and their degree of compliance. The reason for this deviation could relate to the fact that computerized accounting systems are basically designed to possess automated capabilities that are independent of external influences. Since over $98.8 \%$ of the paired indicators are found to have positive relationships, this result of the 
study, therefore, shows that organizational structure exerts some level of influence on the quality of computerized accounting systems. The results of the study support the position of Omar et al. (2016) that there exist a relationship between organizational structure and accounting information systems quality, and that organizational structure is one of the critical factors that influences the quality of accounting information systems among private firms in Kuala Lumpur, Malaysia. The study's results also support Thuan and Huong (2019), whose study result indicated that organizational structure has the greatest impact on the quality of accounting information systems among Vietnam firms.

\subsection{Conclusion and Recommendations}

The study's results indicate that there is a positive relationship between organizational structure and the quality of computerized accounting systems, and that organizational structure exerts positive influence on the quality of computerized accounting systems (accounting information systems) among SMEs in Nigeria. This result implies that the form of organizational structure practiced by an organization plays significant role in determining the quality of its computerized accounting (accounting information) system. However, there is an indication that whether organizations are centralized, formalized, or not, their decision-making process, standards, procedures, rules, regulations, and their level of compliance do not influence the seamless processing and accounts balancing capabilities of the accounting systems employed. The results of this study have implications for the management of SMEs, with respect to the role organizational structure play on the quality of their accounting systems. Suitable organizational structures should, therefore, be maintained by firms to enhance the quality of their accounting information systems and the accounting function generally.

The major limitation of this study is that it focused on only SMEs within the south-south region of Nigeria as the population of the study. However, based on the sampling procedure employed and the reliability of the research instrument, the result of the study can be generalized to the entire body of SMEs in the country. The application of the study's results could also be extended to SMEs in other neighboring West African countries. Further studies are recommended on this area of accounting practice, with samples drawn from different regions of the country to support the results of this study. The influence of other organizational factors such as firm size and organizational culture on the quality of computerized accounting systems among SMEs is also worth investigating. The researcher expects that that the results of the study would bridge the gap in the literature as well as extend the body of knowledge on computerized accounting or accounting information systems.

\section{References}

Agbim, K. C. (2013). The impact of organizational structure and leadership styles on innovation. IOSR Journal of Business and Management, 6(6), 56-63.

American Institute of Certified Public Accountants [AICPA] (1996). AICPA professional standards: Code of professional conduct and bylaws as of June 1, 1996. AICPA Professional Standards - 116. Retrieved from https://egrove.olemiss.edu/aicpa_prof/116

Amidu, M., Effah, J., \& Abor, J. (2011). E-accounting practices among small and medium enterprises in Ghana. Journal of Management Policy \& Practice, 12(4), 146-155.

Anggadin, S. D. (2013).

Bouwens, J., \& Abernethy, M. A. (2000). The consequences of customization on management accounting systems design. Accounting, Organizations and Society, 25(3), 221-259.

Cosh, A., Fu, X., \& Hughes, A. (2012). Organizational structure and innovation performance in different environments. Small Business Economics, 39, 301-317.

Daft, R. L. (2010). Organizational theory and design. (10th ed). Mason, Ohio: South-Western Cengage Learning.

Damanpour, F. (1991). Organizational innovation: A meta-analysis of effects of determinants and moderators. Academy of Management Journal, 34(3), 555-590.

Haleem, A. (2016). The factor affecting computerized accounting system with reference to Government department in the Ampara District. EPRA International Journal of Economic and Business Review, 4(7), $130-139$.

Hurt, R. L. (2013). Accounting information systems: Basic concepts and current issues. 3rd ed. New York: McGraw-Hill/Irwin.

Ismail, N. A., \& King, M. (2006). The alignment of accounting and information systems in SMEs in Malaysia. Journal of Global Information Technology Management, 9(3), 24-42.

Ismail, N. A., \& King, M. (2007). Factors influencing the alignment of accounting information in small and medium sized Malaysian firms. Journal of Information Systems and Small Business, 1(1/2), 1-20.

Itang, A. E. (2017). The impact of computer-based accounting information systems on effectiveness of internal controls in small and medium-sized enterprises in Nigeria (Unpublished master's dissertation). University of Liverpool, Liverpool, United Kingdom.

Itang, A. E. (2018). Challenges impeding effective implementation of internal accounting controls in computerized 
systems: A survey of Nigerian SMEs. Proceedings of the 2018 International Doctoral Conference of LIGS University, Honolulu, USA, August 30, 2018, 69-76. Retrieved from https://www.ligsuniversity.com/data/2018-12-20-11-06-56-International-Doctoral-Conference-of-LIGSUniversity-New-Challenges-in-Global-Economy.pdf

Itang, A. E. (2020a). Computerized accounting systems: Measuring structural characteristics. Research Journal of Finance and accounting, 11(16), 38-54.

Itang, A. E. (2020b). Do small and medium enterprises optimally utilize computerized accounting systems internal controls? An empirical study. Research Journal of Finance and Accounting, 11(20), 16-28.

Janicijevic, N. (2013). The mutual impact of organizational culture and structure. Economic Annals, 58(198), 3560. Proceedings of the 16th Annual Conference of the American Association for Public Opinion Research, May 16-19, 2013, 4351-4360.

Kalay, F., \& Lynn, G. S. (2016). The impact of organizational structure on management innovation: An empirical research in Turkey. Journal of Business, Economics and Finance, 5(1), 125-137.

Kieso, D. E., Weygandt, J. J., \& Warfield, T. D. (2016). Intermediate accounting. 16th ed. USA: John Wiley \& Sons Inc.

Kimmel, P. D., Weygandt, J. J., \& Kieso, D. E. (2011). Financial accounting-tools for decision making. 6th ed. USA: John Wiley \& Sons Inc.

Kpolovie, P. J. (2016). Excellent research methods. Johannesburg: Partridge Publishing.

Krejcie, R. V. \& Morgan, D. W. (1970). Determining sample size for research activities. Educational and Psychological Measurement, 30(3), 607-610.

Kuraesin, A. D., Yadiati, W., Sueb, M., \& Fitrijanti, T. (2019). The effect of management support on quality of accounting information systems and its impact on the quality of accounting information (in private higher education in Bandung City). International Journal of Mechanical Engineering and Technology, 10(3), 450 456.

Laerd Statistics. (n.d.). Pearson Product-Moment Correlation. Retrieved 8/3/2020 from https://statistics.laerd.com/statistical-guides/pearson-correlation-coefficient-statistical-guide.php

Meiryani, M. (2014). Influence of user ability on the quality of accounting information system. International Journal of Economics, Commerce and Management, 11(8), 1-11.

Meiryani, M., Susanto, A., \& Sudrajat, J. (2019). The effect of environmental complexity on the quality of accounting information systems: Integration flexibility and complexity dimensions. ICETT 2019: Proceedings of the 2019 5th International Conference on Education and Training Technologies, May 2019, 115-119. https://doi.org/10.1145/3337682.3337702

Mujat, D-E., Cristescu, M. P., Ciovica, V. L., \& Ciovica, I. L. (2013). The using of open source products in developing the accounting of SMEs. Revista Academiei Fortelor Terestre, 18(4), 411-415.

Mukherji, A. (2002). The evolution of information systems: Their impact on organizations and structures. Management Decisions, 40(5), 497-507.

Nagappan, N., Murphy, B., \& Basili, V. R. (2009). The influence of organizational structure on software quality: An empirical case study. In Proceedings of the $30^{\text {th }}$ International Conference on Software Engineering (pp. 521-530). Association for Computing Machinery. https://doi.org/10.1145/1368088.1368160

Nguyen, H. T., \& Nguyen, A. H. (2020). Determinants of accounting information systems quality: Empirical evidence from Vietnam. Accounting, 6, 185-198.

Nicolaou, A. I. (2011). Integrated information systems and interorganizational performance: The role of management accounting systems design. Advances in Accounting Behavioral Research, 4(1), 117-141.

Ogbo, A. I., Chibueze, N. F., Christopher, O. C., \& Anthony, I. A. (2015). Impact of structure on organizational performance of selected technical and service firms in Nigeria. Corporate Ownership \& Control, 13(1), $1278-1284$

Omar, M. K., Ismail, S., Ying, L. P., \& Yau, T. C. (2016). Factors influencing quality accounting information systems among Malaysian private organizations. Proceedings of 10th Asian-Pacific Business and Humanities Conference, $10, \quad 1-14$ Retrieved from https://www.researchgate.net/publications/301894810_Factors_Influencing_Quality_Accounting_Informati on_Systems_among_Malaysian_Private_Organizations

Salehi, M. \& Abdipour, A. (2011). A study of the barriers of implementation of accounting information system: Case of listed companies in Tehran Stock Exchange. Journal of Economics and Behavioral Studies, 2(2), 7685.

Salhin, A., kyiu, A., Taheri, B., Porter, C., Valantasis-Kanellos, N., \& Konig, C. (2016). Quantitative data gathering methods and techniques. In A. Paterson, D. Leung, W. Jackson, R. Maclntosh, \& K. O'Gorman (Eds.). Research methods for accounting and finance (pp. 168-186). Oxford: Goodfellow Publishers Limited.

Shabbir, M. S. (2017). Organizational structure and employee's performance: A study of brewing firms in Nigeria. American Research Journal of Business and Management, 3(1), 1-16. 
Small and Medium Enterprises Development Agency of Nigeria [SMEDAN]. (2013). SMEDAN and National Bureau of Statistics collaborative survey: Selected findings (2013). SMEDAN. Retrieved 20 May 2018 from https://smedan.gov.ng/images/PDF/2013-MSME-Survey-Summary-Report.pdf

Stair, R. M., \& Reynolds, G. W. (2010). Principles of information systems. 9th ed. Boston, USA: Course Technology.

Susanto, A. (2013). Accounting information systems: Development of risk control structures. Bandung: Lingga Jaya.

Thaun, L. D., \& Huong, T. T. T. (2019). Organizational factors and Quality of accounting information system in Vietnam. Global Journal Al-Thaqafah (GJAT), 9(1), 49-58.

Totten, V. Y., Panacek, E. A., \& Price, D. (1999). Basics of research (part 14) - Survey research methodology: Designing the survey instrument. Air Medical Journal, 18(1), 26-34.

Vazifedoust, H., Nasiri, M., \& Norouzi, A. (2012). Analysing the relationship between organizational structure and employee empowerment in Eastern Azerbaijan. Interdisciplinary Journal of Research in Business, 2(6), $10-24$.

Willem, A., Buelens, M., \& De Jonghe, I. (2007). Impact of organizational structure on nurses' job satisfaction: A questionnaire survey. International Journal of Nursing Studies, 44(6), 1011-1020.

Wisna, N. (2015). Organizational culture and its impact on the quality of accounting information systems. Journal of Theoretical and Applied Information Technology, 82(2), 266-272.

Wyslocka, E., \& Jelonek, D. (2015). Accounting in the cloud computing. Turkish Online Journal of Science \& Technology, 5(4), 1-11.

\section{Appendix}

\section{SAMPLE COPY OF \\ ORGANIZATIONAL STRUCTURE ABD COMPUTERIZED ACCOUNTING SYSTEMS ASSESSMENT QUESTIONNAIRE}

\section{Introduction:}

This questionnaire is a research instrument administered to collect data for a research paper on the influence of organizational structure on computerized accounting systems quality amongst small and medium enterprises in Nigeria. The questionnaire should be completed by someone performing accounting/finance functions (by whatever title) in your organization. The questionnaire is divided into three sections, namely: (A) Demographic Information, (B) Organizational Structure Assessment, and (C) Computerized Accounting Systems Quality Evaluation. Please tick or enter the correct response for each question. This will take about 10 minutes of your time. Be assured that all information will be kept in strict confidence and used only for the purpose of this study. Note that your participation is voluntary and greatly appreciated.

\section{SECTION A: FIRM DEMOGRAPHIC INFORMATION}

A1. Which of the following economic sectors does your business organization belong?
[ ] Manufacturing
[ ] Agriculture
[] Construction
[] Education
[] Wholesale/Retail
[ ] Mining/Quarrying/Oil Servicing
[ ] Accommodation/Food Services [] Transportation/Storage
[ ] Information/Communication
[ ] Arts/Entertainment/Recreation
[ ] Administrative/Support Services
[ ] Other Services/Activities

A2. Which of the following best describes your official job title?
[ ] $\mathrm{CFO} /$ Controller
[ ] Finance/Accounts Manager
[ ] Chief Accountant
[ ] Accountant/Account Officer
[] Auditor

A3. How many employees including management staff does your organization have?
[ ] 10-39
[ ] 40-69
[ ] 70-99
[ ] 100-159
[ ] 160-199

A4. How many employees are involved in the finance/accounting function in your organization have?
[ ] $1-3$
[ ] 7-9
[ ] $4-6$
[ ] 10-12
[] 13 and above

A5. Which of the following accounting software does your organization use?
[ ] BellBook
[ ] MS-Navision
[ ] Busy accounting
[ ] Oracle NetSuite 

[ ] Peachtree/Sage 50
[] QuickBooks
[ ] Sage 300 ERP
[] Sage Evolution
[ ] SAP Business One
[ ] Tally ERP

\section{SECTION B: ORGANIZATIONAL STRUCTURE ASSESSMENT}

The section assesses the organizational structure of your organization in terms of centralization and formalization dimensions based on the following scale:
1 = Strongly disagree (SD)
$2=$ Disagree $(\mathrm{DA})$
$3=$ Undecided $(\mathbf{U N})$
$4=$ Agree (AG)
5 = Strongly agree (SA)

Please tick any of the boxes marked 1-5 as appropriate.

\begin{tabular}{|c|c|c|c|c|c|c|}
\hline $\begin{array}{l}\text { Item } \\
\text { No. }\end{array}$ & Question/Statement & SD & DA & $\mathbf{U N}$ & AG & $\mathbf{S A}$ \\
\hline \multicolumn{2}{|c|}{ Centralization } & 1 & 2 & 3 & 4 & 5 \\
\hline $\mathrm{SC} 1$ & $\begin{array}{l}\text { Our organization uses unique username to identify individual users } \\
\text { of the accounting systems }\end{array}$ & & & & & \\
\hline SC2 & Every user accesses the accounting systems with unique password. & & & & & \\
\hline SC3 & $\begin{array}{l}\text { Our organization's password policy requires periodic password } \\
\text { change. }\end{array}$ & & & & & \\
\hline SC4 & $\begin{array}{l}\text { In our accounting system every user's access is limited to specific } \\
\text { features based on job functions. }\end{array}$ & & & & & \\
\hline SC5 & $\begin{array}{l}\text { Only specific users can perform editing, deleting, and reporting } \\
\text { functions in the accounting system. }\end{array}$ & & & & & \\
\hline SC6 & Our accounting system is managed by a dedicated administrator. & & & & & \\
\hline \multicolumn{2}{|c|}{ Formalization } & 1 & 2 & 3 & 4 & 5 \\
\hline SF1 & $\begin{array}{l}\text { Our accounting system only accepts dates and numeric entries in } \\
\text { specified formats. }\end{array}$ & & & & & \\
\hline SF2 & $\begin{array}{l}\text { Our accounting system is set up to prevent duplicated source } \\
\text { document entries. }\end{array}$ & & & & & \\
\hline SF3 & $\begin{array}{l}\text { Our accounting system is set up to prevent wrong data type entries } \\
\text { (e.g. numeric Vs alphabets). }\end{array}$ & & & & & \\
\hline SF4 & $\begin{array}{l}\text { In our accounting system, data files are schedules for } \\
\text { regular/periodic backups. }\end{array}$ & & & & & \\
\hline
\end{tabular}

\section{SECTION C: COMPUTERIZED ACCOUNTING SYSTEM QUALITY EVALUATION}

The section evaluates the quality of the computerized accounting system used by your organization in five dimensions based on the following scale:
$1=$ Strongly disagree $(\mathrm{SD})$
2 = Disagree $(\mathrm{DA})$
$3=$ Undecided $(\mathbf{U N})$
$4=$ Agree (AG)
5 = Strongly agree (SA)

Please tick any of the boxes marked 1-5 as appropriate.

\begin{tabular}{|c|c|c|c|c|c|c|}
\hline $\begin{array}{l}\text { Item } \\
\text { No. }\end{array}$ & Question/Statement & SD & DA & $\mathbf{U N}$ & $\mathbf{A G}$ & SA \\
\hline \multicolumn{2}{|c|}{ Internal controls } & 1 & 2 & 3 & 4 & 5 \\
\hline IC1 & $\begin{array}{l}\text { In our computerized accounting system predefined users only can have } \\
\text { access to the system with the use of passwords }\end{array}$ & & & & & \\
\hline IC2 & $\begin{array}{l}\text { In our computerized accounting system users are assigned specific roles } \\
\text { to ensure segregation of duties. }\end{array}$ & & & & & \\
\hline IC3 & $\begin{array}{l}\text { Our computerized accounting system checks and confirms the accuracy } \\
\text { of data entered in the systems }\end{array}$ & & & & & \\
\hline IC4 & $\begin{array}{l}\text { Our computerized accounting system is protected from intrusions, } \\
\text { information theft, and data manipulation. }\end{array}$ & & & & & \\
\hline IC5 & $\begin{array}{l}\text { Our computerized accounting system can provide audit trail on users } \\
\text { and transactions. }\end{array}$ & & & & & \\
\hline
\end{tabular}




\begin{tabular}{|c|c|c|c|c|c|c|}
\hline $\begin{array}{l}\text { Item } \\
\text { No. }\end{array}$ & Question/Statement & SD & DA & $\mathbf{U N}$ & $\mathbf{A G}$ & SA \\
\hline \multicolumn{2}{|c|}{ Automated data-processing } & 1 & 2 & 3 & 4 & 5 \\
\hline AP1 & $\begin{array}{l}\text { Our computerized accounting system performs tasks and processes } \\
\text { seamlessly. }\end{array}$ & & & & & \\
\hline AP2 & $\begin{array}{l}\text { Our computerized accounting system has data validation } \\
\text { functionalities. }\end{array}$ & & & & & \\
\hline AP3 & $\begin{array}{l}\text { Our computerized accounting system performs transactions posting } \\
\text { automatically. }\end{array}$ & & & & & \\
\hline AP4 & $\begin{array}{l}\text { Our computerized accounting system performs accounts balancing } \\
\text { functions automatically }\end{array}$ & & & & & \\
\hline AP5 & $\begin{array}{l}\text { Our computerized accounting system has accounts reconciliation } \\
\text { functionality. }\end{array}$ & & & & & \\
\hline \multicolumn{2}{|r|}{ Relational database } & 1 & 2 & 3 & 4 & 5 \\
\hline RD1 & Our computerized accounting system can store large collection of data. & & & & & \\
\hline RD2 & $\begin{array}{l}\text { Our computerized accounting system enhances the maintenance and } \\
\text { retrieval of large collections of data. }\end{array}$ & & & & & \\
\hline RD3 & $\begin{array}{l}\text { Our computerized accounting system ensures the independence and } \\
\text { integrity of data. }\end{array}$ & & & & & \\
\hline RD4 & $\begin{array}{l}\text { Our computerized accounting systems ensures the security, back-up, } \\
\text { and recovery of data. }\end{array}$ & & & & & \\
\hline RD5 & $\begin{array}{l}\text { Our computerized accounting system ensures concurrent access to data } \\
\text { and information in the system. }\end{array}$ & & & & & \\
\hline \multicolumn{2}{|r|}{ Automated reporting } & 1 & 2 & 3 & 4 & 5 \\
\hline AR1 & $\begin{array}{l}\text { Our computerized accounting system generates financial statements } \\
\text { and reports seamlessly. }\end{array}$ & & & & & \\
\hline AR2 & $\begin{array}{l}\text { Our computerized accounting systems can generate the Trial balance } \\
\text { and other general ledger reports automatically. }\end{array}$ & & & & & \\
\hline AR3 & $\begin{array}{l}\text { Our computerized accounting system can generate various financial } \\
\text { statements (e.g. Income statement, Balance sheet, etc.). }\end{array}$ & & & & & \\
\hline AR4 & $\begin{array}{l}\text { Financial statements and reports can be generated from our } \\
\text { computerized accounting system based in multiple formats and } \\
\text { reporting options. }\end{array}$ & & & & & \\
\hline AR5 & $\begin{array}{l}\text { Our computerized accounting system can generate financial statements } \\
\text { with comparative figures. }\end{array}$ & & & & & \\
\hline \multicolumn{2}{|r|}{ Enhancing technologies } & 1 & 2 & 3 & 4 & 5 \\
\hline ET1 & $\begin{array}{l}\text { Our computerized accounting system is (or could be used) on a } \\
\text { network. }\end{array}$ & & & & & \\
\hline ET2 & $\begin{array}{l}\text { Our computerized accounting system is (or could be migrated to) cloud } \\
\text { based. }\end{array}$ & & & & & \\
\hline ET3 & $\begin{array}{l}\text { Our computerized accounting system can interface with Point of Sale } \\
\text { (POS) devices. }\end{array}$ & & & & & \\
\hline ET4 & $\begin{array}{l}\text { Our computerized accounting system supports documents upload and } \\
\text { attachments. }\end{array}$ & & & & & \\
\hline ET5 & Our computerized accounting system supports E-mail/SMS facilities. & & & & & \\
\hline
\end{tabular}

END OF QUESTIONNAIRE... THANKS FOR YOUR PARTICIPATION!

Source: Adapted from Kalay and Lynn (2016) and Itang (2020a) 